Отримано: 29.05.2019 р.

Прорецензовано: 12.06.2019 р.

Прийнято до друку: 10.07.2019 р.

e-mail: andrii.smyrnov@oa.edu.ua

DOI: $10.25264 / 2409-6806-2019-28-145-149$
Смирнов А. Усунення варшавського митрополита Діонісія Валединського і початок реорганізації православної церкви в окупованій Польщі (19391940). Наукові записки Наиіонального університету «Острозька академія». Серія «Історичні науки». Острог, 2019. Вип. 28. С. 145-149.

\title{
Андрій Смирнов
}

\section{УСУНЕННЯ ВАРШАВСЬКОГО МИТРОПОЛИТА ДІОНІСІЯ ВАЛЕДИНСЬКОГО І ПОЧАТОК РЕОРГАНІЗАЦІЇ ПРАВОСЛАВНОЇ ЦЕРКВИ В ОКУПОВАНІЙ ПОЛЬЩІ (1939-1940)}

У статті проаналізовано політику німецької влади щодо Православної Церкви в Генерал-губернаторстві в 1939-1940 рр. Під час нацистської окупаџї Польщі вона зазнала суттєвої реорганізаuіï, яка передбачала усунення митрополита Діонісія і призначення Берлінського архієпископа Серафима Ляде тимчасовим керівником Варшавської єпархї. Більшість німецьких відомств прагнула зберегти автокефалію Православної Церкви в Генерал-губернаторстві. Уважалося, що вона була надана не польській державі, а православному населенню, і тому має право на існування в нових умовах. Вихований в російських традиціях, владика Серафим почав проводити відверто русифікаторську політику.

Ключові слова: Діонісій Валединський, Серафима Ляде, Православна Церква, Генерал-губернаторство, україниі, автокефалія.

\section{Andrii Smyrnov}

\section{THE REMOVING OF THE METROPOLITAN DIONISII VALEDYNSKYI OF WARSAW AND THE BEGINNING OF THE REORGANIZATION OF THE ORTHODOX CHURCH IN GERMAN-OCCUPIED POLAND}

The article deals with the policy of the German authorities concerning the Orthodox Church in General Government from 1939 till 1940. The division of the Polish territory between Germany and the Soviet Union left only one of the five former Orthodox eparchies of Poland, the Warsaw-Kholm eparchy, in the General Government. The reduced hierarchy of this German-controlled Orthodox Church consisted of Metropolitan Dionisii Valedynskyi of Warsaw and bishop Tymofii Shretter.

In November 1939 the beleaguered Metropolitan Dionisii, attacked by Russian nationalists, was forced by the Gestapo to resign in favour of an outsider archbishop Seraphim Lade of Berlin. He belonged to the Russian Orthodox Church Abroad and promoted German interests. Officially, however, Dionisii attributed his transfer of authorities to Seraphim to "the new political and administrative conditions created by the demise of Poland". The majority of Nazi agencies supported the autocephaly of the Orthodox Church in General Government. They considered autocephaly as granted to Polish state, not to the Orthodox people. Archbishop Seraphim, educated in Russian traditions, began to implement strong pro-Russian policies. He started the reorganization of church administration and created eparchial Bishop's Council instead of consistory. However, under the German and Ukrainian pressure Seraphim was obliged to make concessions for the Ukrainians and accept Polish autocephaly.

Key words: Dionisii Valedynskyi, Seraphim Lade, the Orthodox Church, General Government, Ukrainians, autocephaly.

Православна Церква в міжвоєнній Польщі, очолювана митрополитом Діонісієм Валединським, у 1924 р. отримала томос про автокефалію від Вселенського Патріархату як колишня частина давньої Київської Митрополії. Польський уряд прагнув використати ії для державної асиміляції українського населення і в другій половині 1930-х рр. проголосив курс на форсовану полонізацію православ'я. Така політика Польської держави призвела до погіршення міжконфесійної ситуації i, на думку Ю. Крамара, стала одним із вагомих чинників загострення польсько-українських відносин напередодні Другої світової війни [4, с. 320].

Польська Автокефальна Православна Церква на 1939 р. охоплювала 5 єпархій, 2 духовні семінаpiï, 340 деканатів, 1160 парафій і 1792 священнослужителя. В основному це були українці, білоруси і 
росіяни. Холмщина і Підляшшя належало до Варшавсько-Холмської єпархії, до складу якої 7 листопада 1938 р. Синод єпископів передав Берестейщину, Ковельщину і Любомльщину. За рахунок цих церковно-територіальних змін митрополича єпархія, яка зазнала великих втрат під час ревіндикації, у 1939 р. зросла до 258 парафій і налічувала 821 тис. православних християн [14, s. 122-123].

Вибух Другої світової війни призвів до значних змін у житті Православної Церкви на території Західної України. Пакт Молотова-Ріббентропа територіально розділив ПАПЦ на дві не рівні частини. Відтак Холмщина і Підляшшя потрапили до складу Генерал-губернаторства, а найбільша Волинська єпархія опинилася в межах СРСР. 1 вересня 1939 р. владика Діонісій у спеціальному посланні, згадуючи звитягу гетьмана Костянтина Острозького, закликав усіх вірних Православної Церкви до захисту Польської держави: «Я твердо вірю, що православні громадяни Речі Посполитої ревно виконають цей святий і почесний обов'язок, що не забракне їх у перших лавах нашої переможної армії» [7, c. 255].

Православні парафії на теренах, включених до ІІІ-го Райху, перейшли в юрисдикцію архієпископа Берлінського і Германського Серафима Ляде (1883-1950). Він належав до Російської Православної Церкви за кордоном (РПЦЗ) і вважався у Берліні головним експертом із церковних справ. Оскільки Синод цієї Церкви не визнавав польської автокефалії, але переймався становищем православного населення окупованої Польщі, то доручив архієпископу Серафиму надати допомогу Варшавській єпархії.

Водночас, як інформував невідомого адресата свідок тих подій з оточення митрополита Діонісія, у Варшаві значно активізувався Російський громадський комітет, що прагнув підпорядкувати православні парафії карловацькій юрисдикції і таким чином позбутися автокефалії [10]. Лідери російської громади пропонували очолити Церкву вікарному єпископу Тимофію Шреттеру (1901-1962), але він не користувався підтримкою окупантів через своє «полонофільство» і незабаром був засланий до Яблочинського монастиря.

Керуючись рішенням свого Синоду і реагуючи на звернення російських кіл, за підтримки Міністерства церковних справ 10 листопада 1939 р. архієпископ Серафим прибув до Варшави для того, щоб вивчити церковну ситуацію і перебрати керівництво єпархією. Аналіз нововиявлених документів дає підстави стверджувати, що він зустрічався з митрополитом Діонісієм, російськими діячами і представниками німецьких органів влади. Зокрема, митрополит відмовився передавати справи і тільки погодився увійти до складу Ради православних єпископів Німеччини, Протекторату і Генерал-губернаторства. За результатами поїздки архієпископ Серафим підготував звіт для міністерства, куди також планував виїхати владика Діонісій, але 16 листопада був заарештований гітлерівцями $[10 ; 15$, s. 70$]$.

Польські та російські дослідники схильні пояснювати відмову митрополита Діонісія від управління Церквою тиском німецької влади. І. Власовський, посилаючись на О. Світіча, твердив, що вирішальний вплив на прийняття ним цього рішення мала російська громада Варшави: «Під тиском цього „церковного народае митр. Діонісій і написав, чи підписав 23 листопада 1939 р. листа архієпископові Серафимові» [2, с. 179].

Правдоподібно, владика Діонісій усе ж став жертвою доносів з боку росіян та деяких українців, які в міжвоєнний період були не задоволенні його позицією у національному питанні. Зокрема, проти нього виступали провідники Російського громадського комітету С. Войцеховський і прот. Д. Сайкович, а також група проф. М. Зизикіна. Через це митрополитові неодноразово довелося ходити на допити в гестапо. «Приводом для цього були наклепи на нього з боку російських організацій, котрі були незадоволені ним і його діяльністю, як глави Автокефальної Православної Церкви в Польщі... За допомогою німецького гестапо вони сподівалися досягти своєї мети», - згадував архімандрит Афанасій Мартос, який тоді мешкав у митрополичому домі у Варшаві [1]. Підтвердженням вищенаведеного є фрагмент спогадів політичного і громадського діяча білої еміграції С. Войцеховського, який згадував, що о. Д. Сайкович був противником польської автокефалії, митрополита Діонісія і вітав його усунення. «До 1939 року я був завзятим, непримиренним і - повинен зізнатися - не завжди справедливим противником його політики», - писав С. Войцеховський [3]. Під час зустрічі в Берліні з Георгом Ляйбрандтом, нащадком німецьких колоністів із Одещини, який очолював службу «Схід» зовнішньополітичного управління НСДАП, С. Войцеховський наполягав на скасуванні автокефалії, усуненні Валединського, приєднанні Варшавської Митрополії до Берлінської єпархії і призначенні владики Серафима очільником об'єднаної Церкви [15, s. 78-79]. 
Крім того, як випливає зі спогадів В. Кубійовича, «тодішній Український комітет у Варшаві під проводом д-ра Юрія Липи був виразником неприязного ставлення українців до митрополита Діонісія і немало спричинився до утруднення його позиції в новій німецькій дійсності, даючи про нього німцям негативні й односторонні інформації» [5, с. 298]. Колоритну характеристику очільника Українського допомогового комітету подав правознавець А. Яковлів: «При цих кількоразових візитах до гестапо бачив я там д-ра Липу, що утворив тоді Комітет український, сам себе призначив його головою й старався грати ролю якогось українського „фюрера ного» $[6$, с. 97].

22 листопада митрополит Діонісій був змушений написати листа владиці Серафиму: «Позбавлений фізичної можливості через незалежні від мене обставини звершувати богослужіння і виконувати архіпастирські обов'язки щодо своєї пастви, я прошу Ваше Високопреосвященство приїхати найближчими днями до Варшави і прийняти тимчасово в свос відання і управління православні парафії, які знаходяться на території б. Польщі, що входить нині до складу Генерал-губернаторства. Про подальше ми своєчасно доповімо святішому патріарху Веніаміну в Константинополь і високопреосвященішому митрополиту Анастасію в Сремських Карловцях» [10]. Одначе не задоволені цим текстом гітлерівці не дозволили надіслати лита в Берлін. Наступного дня владика під тиском «представників німецької політичної влади» (за деякими даними гестапо погрожувало йому концтабором) підписав інший документ, у якому йшлося про припинення автокефального існування Польської Церкви і відмову від керівництва нею на користь владики Серафима: «Я повідомляю Вам, що 3 дня вступу Вашого в управління я відмовляюся від подальшого управління названою Церквою» $[9$, с. 90-91; 10; 13]. 27 листопада він відправив прощальне богослужіння у нижньому храмі собору, передав свої повноваження і надалі мешкав під домашнім арештом в Отвоцьку. Незабаром були репресовані найближчі співробітники митрополита: особистий секретар Сергій Юденко загинув у нацистському концтаборі Маутгаузен, а директор митрополичої канцелярії Юрій Рошчицький був замордований гітлерівцями в Дахау [12, s. 77].

Варто зауважити, що владика Діонісій, який вимушено тимчасово відмовився від адміністративної влади над митрополією, не втратив свого архієрейського титулу. Духовенство, в тому числі архієпископ Серафим, продовжувало поминати його ім'я за богослужінням. У німецьких документах таке поєднання ним двох посад без об’єднання Берлінської і Варшавської єпархій в одну структуру називалося «персональною унією», яка, щоправда, носила тимчасовий характер на перехідний період. «Автокефальна Православна Церква Польщі в цей час керується Вами, пане архієпископе, так що нині є персональна унія між Православною Церквою Німеччини і тієї колишньої Польщі. Але жодним чином не слід дотримуватися погляду, що дотепер Православна Церква Польщі розчинилася в Православній Церкві Німеччини», - наголошував відділ церковних справ Генерал-губернаторства у листі до владики Серафима $[10 ; 16]$.

Отже, з ініціативи Міністерства церковних справ окупанти, що вдало використали внутрішньоцерковні міжнаціональні непорорузімння та конфлікти, усунули митрополита Діонісія від обов'язків першоієрарха, намагаючись підпорядкувати православне населення загарбаних земель Берлінському архієпископу. Це повністю вписувалося у рамки міністерської політики творення наднаціональної Православної Церкви в Німеччині та окупованих нею територіях. Розширення Берлінської єпархії РПЦЗ було закономірним й цілком відповідало інтересам Райху.

Водночас, як стверджує М. Шкаровський, резигнація владики Діонісія на користь архієпископа Серафима стала несподіваною для уряду генерал-губернатора Г. Франка. Німецькі партійні та державні органи, не довіряючи митрополиту через його антинімецьке звернення від 1 вересня 1939 р., ще не мали узгодженої позиції щодо подальшої долі ПАПЦ і продовжували вести міжвідомчі консультації. Зокрема, Міністерство церковних справ підтримувало владику Серафима і приєднання iii Варшавської єпархії до Райху, а Міністерство закордонних справ (МЗС), зовнішньополітична служба НСДАП і уряд генерал-губернатора прагнули зберегти автокефалію Православної Церкви в Генерал-губернаторстві. Уважалося, що вона була надана не Польській державі, а православному населенню, і тому має право на існування в нових умовах.

Використовуючи імперський принцип «розділяй та володарюй», окупанти надавали преференції українському православному населенню цих земель і загравали з його лідерами. Наприклад, у службовій записці МЗС до Міністерства церковних справ від 18 грудня 1939 р. зазначалося, що «релігійно налаштовані українці... являють собою дуже цінний фактор у якості противаги полякам, 
чого не можна сказати про нейтральних до поляків російських емігрантів» [цит. за: 8, с. 96]. Доповідна записка зовнішньополітичних аналітиків НСДАП від 4 грудня 1939 р. уже містила конкретні рекомендації щодо церковної політики в Генерал-губернаторстві: «Якщо Українська Церква в Українській державі хоче бути автокефальною, то вона повинна домогтися дозволу з боку Матері-Церкви (російської або польської). 3 цієї причини важливо, щоб нинішня автокефальна Польська Церква зберегла свою самостійність і надалі... Українсько-польська боротьба часто велася в рамках релігійної боротьби. Тому було б доцільно заснувати зараз православне єпископство в Холмі, призначити в Холм українського архієрея і відібрані поляками православні церкви знову повернути українським православним у холмській землі» [13]

За згодою Синоду РПЦЗ архієпископ Серафим тимчасово переїхав до Варшави, потрапив під уплив місцевих російських середовищ і одразу (18 грудня) видав низку контроверсійних розпоряджень. Наприклад, заснував братство імені св. Володимира на чолі з о. Д. Сайковичем, повернув старий літургійний календар, заборонив духовенству голити бороди і хрестити євреїв, а також відновив холмське Різдво-Богородичне братство. Керуючись ухвалою карловацького Синоду за 1936 р., владика Серафим установив формулу поминання державної влади на великій єктенії: «За христолюбивого вождя народу німецького, уряд і воїнство його, Господу помолимось» [17, s. 57-58]. Крім того, 21 лютого 1940 р. відбулася реорганізація церковного управління єпархією: замість духовної консисторії створювалася єпархіальна єпископська рада, до якої увійшли російські священики $[7$, c. $258-259 ; 15$, s. 76].

Щодо позиції німецьких чинників в українському церковному питанні, то станом на січень 1940 p. більшість представників державних і партійних відомств уважали ідеальним, якби в Генерал-губернаторстві була утворені автокефальна українська Церква. У листі від 28 січня 1940 р., адресованому архієпископу Серафиму, відділ церковних справ Генерал-губернаторства висловився категорично проти скасування автокефалії, але водночас наполягав, що «ще не настав час для обрання єпископа на Холмщину» [10; 16]. 21 лютого 1940 р. начальник головного реферату «Схід» МЗС Німеччини Петер Кляйст у листі міністру церковних справ Гансу Керрлу виступив за українізацію Православної Церкви як запоруку лояльного ставлення українців до Німеччини [11]. Представники Головного управління імперської безпеки вважали цілком прийнятною пропозицію заснувати самостійну українську єпархію з центром у Варшаві [8, с. 99-100]. Як наслідок, у лютому генерал-губернатор Франк і міністр Керрл домовилися про офіційний перехід на час війни церковного керівництва до архієпископа Серафима за умови невтручання першоісрарха РПЦЗ митрополита Анастасія Грибановського у внутрішні справи Варшавської єпархії, збереження автокефалії і призначення українських священиків [15, s. 71-72].

3 огляду на це владика Серафим, усупереч своїм переконанням, змушений був піти на значні поступки православним українцям. По-перше, він письмово запевнив, що не буде вживати заходів, які могли б призвести до ліквідації автокефалії Православної Церкви в Генерал-губернаторстві. По-друге, відмовився від ідеї перенесення своєї резиденції з Берліна до Варшави. По-третє, висловив готовність невдовзі зробити такі кроки: призначати священиків-українців на українські парафії; збереження виступів і проповідей за богослужінням українською мовою; служіння літургії церковнослов'янською мовою з українською вимовою. Крім того, архієпископ повідомив, що збирається призначити українського священика адміністратором Холмщини, розпустити православну консисторію у Варшаві та звільнити ії російських службовців. Водночас, як небезпідставно твердить М. Шкаровський, «обіцянка нічого не робити проти автокефалії зовсім не означала її визнання, мабуть, архієп[ископ] Серафим був змушений тимчасово „заплющити очіе на формальне продовження iї незаконного існування» [8, с. 98]. Спочатку українці покладали на нього певні надії, сподіваючись, що він сприятиме українському церковному відродженню, але швидко розчарувалися. Вихований в російських традиціях, владика Серафим почав проводити відверто русифікаторську політику $[7$, c. $258 ; 14$, s. 201].

В анонімному листі українського інформатора з Варшави від 11 лютого 1940 р., що надійшов до зовнішньополітичної служби НСДАП, зазначалося: «Генер[ал]-губ[ернатор] підкреслює абсолютну шкідливість підпорядкованості Православної Церкви Карловацькому Собору та наказує архієпископові Серафиму справи церковні вести так, щоб „ніде не нагадувало про нібито знесену автокефаліюе. Висловлює побажання, щоб владика розпустив митропол[ичий] совіт (чисто російський) та переніс свою резиденцію до Холма. Владика проти цього останнього борониться». Далі автор 
інформації повертається до питання усунення владики Діонісія, якого росіяни за допомогою чотирьох офіцерів німецької армії змусили підписати листопадового листа. «Росіянам ішло головно про знесення автокефалії, котрої вони ніколи не признавали. Хиба сталася з вини митрополита Діонісія, котрий, як виявляється, ніколи до українців вороже не ставився та після війни ішов разом з українцями», - йшлося у повідомленні [13].

Отже, Православна Церква в окупованій Польщі зазнала суттєвої реорганізації, яка передбачала усунення митрополита Діонісія і призначення Берлінського архієпископа Серафима тимчасовим керівником Варшавської єпархії. Більшість німецьких відомств прагнула зберегти автокефалію Православної Церкви в Генерал-губернаторства. Уважалося, що вона була надана не Польській державі, а православному населенню, і тому має право на існування в нових умовах. Вихований в російських традиціях, владика Серафим почав проводити відверто русифікаторську політику.

\section{Список використаних джерел та літератури:}

1. Афанасий (Мартос), архиеп. На ниве Христовой. URL: https://www.fatheralexander.org/booklets/russian/ na_\%20nive_hristovoj_archb_athanasios.htm (дата звернення: 12.02.2019).

2. Власовський І. Нарис історії Української православної церкви: В 4 т., 5 кн. Київ, 1998. Т. 4: (ХХ ст.). Ч. 2. 399 c.

3. Войцеховский С. Эпизоды. Лондон (Канада), 1978. 189 с.

4. Крамар Ю. В. Західна Волинь 1921-1939 рр.: національно-культурне та релігійне життя. Луцьк, 2015. $404 \mathrm{c}$.

5. Кубійович В. Українці в Генеральній Губернії. 1939-1941. Історія Українського Центрального Комітету. Чикаго, 1975. 664 с.

6. Матяш І. «Той час не був часом чудес...» (Спомини Андрія Яковлєва «з років всесвітньої війни 1935 1945»). Пам'ятки. 2007. Т. 7. С. 75-109.

7. Свитич А. Православная Церковь в Польше и ее автокефалия. Православная Церковь на Украине и в Польие в ХХ столетии. 1917 - 1950 г2.: Сборник. Москва, 1997. С. 87-293.

8. Шкаровский М. В. Крест и свастика: Нацистская Германия и Православная Церковь. Москва, 2007. 507 с.

9. Шкаровский М. Политика Третьего рейха по отношению к Русской Православной Церкви в свете архивных материалов (Сборник документов). Москва, 2003. 366 с.

10. Archiwum Warszawskiej Metropolii Prawosławnej. Sygn. 1029-RII-6D (Prawosławna Cerkiew w GenerałGubernatorstwie).

11. Bundesarchiv Berlin, NS 43/32. B1. 81-82, 94-95.

12. Dudra S. Metropolita Dionizy (Waledyński), 1876-1960. Warszawa, 2010. 247 s.

13. Institut für Zeitgeschichte München (IFZ), MA-128/7.

14. Mironowicz A. Kościół prawosławny na ziemiach polskich w XIX i XX wieku. Białystok, 2005. $390 \mathrm{~s}$.

15. Sziling J. Kościoły chrześcijańskie w polityce niemieckich władz okupacyjnych w Generalnym Gubernatorstwie (1939-1945). Toruń, 1988. 228 s.

16. University of Alberta Archives, Minenko Collection, box 2, item 11.

17. Urban K. Kościół prawosławny w Polsce 1945-1970 (rys historyczny). Kraków, 1996. 412 s.

\section{REFERENCES}

1. Dudra S. Metropolita Dionizy (Waledyński), 1876-1960. Warszawa, 2010. 247 s.

2. Kramar Yu. V. Zakhidna Volyn 1921-1939 rr.: natsionalno-kulturne ta relihiine zhyttia. Lutsk, 2015, 404 s.

3. Kubiiovych V. Ukraintsi v Heneralnii Hubernii. 1939-1941. Istoriia Ukrainskoho Tsentralnoho Komitetu. Chykaho, 1975. $664 \mathrm{~s}$.

4. Matiash I. «Toi chas ne buv chasom chudes...» (Spomyny Andriia Yakovlieva «z rokiv vsesvitnoi viiny 1935 1945») Pamiatky. 2007. T. 7. S. 75-109.

5. Mironowicz A. Kościół prawosławny na ziemiach polskich w XIX i XX wieku. Białystok, 2005. $390 \mathrm{~s}$.

6. Shkarovskiy M. Politika Tret'ego reykha po otnosheniyu k Russkoy Pravoslavnoy Tserkvi v svete arkhivnykh materialov (Sbornik dokumentov). Moskva, 2003. 366 s.

7. Shkarovskiy M. V. Krest i svastika: Natsistskaya Germaniya i Pravoslavnaya Tserkov'. Moskva, 2007. 507 s.

8. Svitich A. Pravoslavnaya Tserkov'v Pol'she i ee avtokefaliya Pravoslavnaya Tserkov'na Ukraine $i$ v Pol'she $v$ XX stoletii. 1917 - 1950 gg.: Sbornik. Moskva, 1997. S. 87-293.

9. Sziling J. Kościoły chrześcijańskie w polityce niemieckich władz okupacyjnych w Generalnym Gubernatorstwie (1939-1945). Toruń, 1988. 228 s.

10. Vlasovskyi I. Narys istorii Ukrainskoi pravoslavnoi tserkvy. Kyiv, 1998. T. 2. Ch. 2. 399 s. 